\title{
Hermafroditska žena. Retorika spolnosti i femininosti u novelistici A.G. Matoša (na primjeru Cvijeta sa raskršća)
}

\begin{abstract}
Vuković Tvrtko, Žužul Ivana, Hermafroditska žena. Retorika spolnosti i femininosti u novelistici A.G. Matoša (na primjeru Cvijeta sa raskršća) (Hermaphrodite Woman. The Rhetoric of Sexuality and Femininity in the Short Stories of A.G. Matoš [the Example of the Short Story Crossroads Flower]). „Poznańskie Studia Slawistyczne” 7. Poznań 2014. Publishing House Science and Innovate, pp. 247-258. ISBN 978-83-63795-79-5. ISSN 2084-3011.

The literary work of A.G. Matoš is characterized by a strong interest in femininity and sexuality. The analyses of female's figures and sexuality in the author's oeuvre have strived to imbue these concepts with stable meaning. Our thesis is that sexuality and the rhetoric of femininity are generally unreadable and ambiguous, and that their direct, literal interpretations are based on their unconscious exclusion. The example of the short story Cvijet sa raskršća (Crossroads Flower) shows that the rhetoric of femininity works as a drive of the text and its reading, and that the interpretations, trying to calm the ambiguity of that concept, remain blind to the blindness of insight, for what the text sets as a necessary condition of its own reading and understanding.
\end{abstract}

Keywords: modernism; rhetoric; sexuality; femininity; short story; psychoanalysis; blindness of reading

U pismu Vladimiru Lunačeku - 14. rujna 1909. - vidno nezadovoljan kritikom svojih radova koju je njegov prijatelj objavio u „Obzoru” Matoš negodujući pojašnjava: 
Ja znam biti psiholog, ali u tim mnogim pričama sam simbolist: tu je psihologija (analiza) suvišna. Čudim se, kako ti se od svega toga nije najviše svidio Cviet sa raskršća. Sliepa i aristokratska pucica je simbol svega, što nas ljubi, ali što mi - ne možemo uživati. Uzmi moje starije priče, gdje ima realnih žena i naći ćeš, da ih dosta poznam. Onaj tvoj citat (Helena, Fornarina, Saloma itd.) ne vrijedi za mene nego za artista, koji sve te žene kao plastiker grčki, generalizirajući i ne diferencirajući, gutira. Šteta što nisi bio u Parizu, pa bi u meni našao više Barrèsa no Wildea i Przb (Przybyszewskog, op. a.). Od njega sam i kao nacionalist dosta naučio. Simboliši osobu, ženu, i ti si je 'šablonirao'. Kako dolaziš do toga, da od simbolski određenih figura tražiš individualizirane crte? (Matoš 1973b: 245-246; istaknuli T.V. i I.Ž.).

Čini se da je svojim artističkim projektom Matoš težio objedinjavanju žudnje i retorike. Povezujući nemogući užitak i ,šablonu” simbola, drugim riječima nastojeći da u njegovu radu doslovno izbije neoznačivo u materijalu označitelja, želio se riješiti vulgarnog psihologizma. Zato je valjda, kako sam kaže, prosuo „malo žuči” (Matoš 1973b: 246) kada se morao suočiti s Lunačekovom individualizacijom simbola, s brkanjem književnosti i stvarnosti, slova i fenomena. „Ti kao i drugi odviše zamjenjuješ u meni novinara sa - književnikom" (Matoš 1973b: 246). Posve je jasno da je Matošu ova zbrka najveća uvreda. Lunačekova fenomenologizacija simboličkog jezika književnosti u njemu budi osjećaj ,zajedavanog zajedatora" (Matoš 1973b: 246), ali bi tu reakciju iznova bilo pogrešno tumačiti psihološki. Matoš ovdje ne staje u obranu svoje povrijeđene taštine, nego u obranu ideje literarnosti koju su njegovi ondašnji, a i mnogi današnji čitatelji i analitičari iz različitih razloga previđali i prešućivali.

Da ova za Matoša uznemirujuća pometnja u shvaćanju odnosa književne i prirodne stvarnosti nije nimalo bezazlena, svojedobno je upozoravao i de Man kada ju je doveo u vezu s ideološkim mišljenjem ${ }^{1}$. Ima li Matošev književni artizam danas kakvu protuideološku snagu, onda je ona skupljena u ludilu njegove retorike, u onome što Shoshana Felman naziva la chose littéraire. Ta čudna književna stvar svakako nije književnost kao institucija, nego ,izvorni, stvaralački nagon koji nas navodi na čitanje. To je ono što tekst čini književnim, što ga pretvara u događaj, što uspostavlja

1 „Ono što zovemo ideologijom upravo je to brkanje lingvističke i prirodne zbilje ili referencije i fenomenalizma (samih objekata)" (de Man 1986: 11). 
njegov književni život, njegovu trajnu emocionalnu i retoričku vitalnost" (Felman 2003: 5). Vitalnost Matoševih tekstova Lunaček je očito prebrzo institucionalizirao. Ono oko čega obigrava neiscrpivo kretanje čitanja i što je u svojoj osnovi pitanje samog jezika, točnije označavanja i u njega upisane neoznačivosti, Lunaček je priveo ideologiji književnosti kao pukom odrazu stvarnosti. Matoš pak „kao plastiker grčki” koristi jezični materijal da bi izradio objekte koji nemaju zbiljsku referenciju. Od doslovno različitih imena - „Helena, Fornarina, Saloma” - izrađuje apstrakciju kojoj je označiteljski materijal imanentan. Apstrakcija ima „tvrdoću”, ali ne upućuje ni na koju stvarnu osobu, niti na bilo što drugo konkretno. Može se tek „gutirati”, zagonetno Lunačeku docira Matoš. Posve je nejasno o čemu je tu riječ, ali je jasno da je taj artistički užitak, užitak u artizmu, neodrediv. Proizvod je retoričke izvedbe koja sebe ušutkava u mjestu odakle se artikulira: konkretna apstrakcija, transcendentalna imanencija ${ }^{2}$. Za očekivati je da se na tom mjestu artikulacije nađe subjekt spoznaje: pisac, čitatelj. Međutim, to se mjesto sviješću ne može zaposjesti. Prije je riječ o tome da je svijest zaposjednuta njime. S toga nemogućeg, neprozirnog mjesta subjekt ne ustaje da bi govorio, nego nešto drugo, neko drugo doslovno izranja iz njega i govori ga. Možda zbog toga Matoš ima potrebu kurzivom naglasiti da je ,simbolist”, onaj koji, prema etimološkom značenju riječi, koristi nešto što su-postoji (sim-bol), i čiji je rad uvijek neko drugo od sebe. On je i ,artista" također u doslovnom značenju riječi, onaj koji spaja različite stvari (arma, artus, artio), kombinira ih tako da djeluju zajedno onkraj njihove izvorne svrhe. Valjda i zato nervozno zapitkuje Lunačeka: „Kako dolaziš do toga, da od simbolski određenih figura tražiš individualizirane crte?" Drugim riječima, kako to da u slijepu točku retoričkog rada kojim

2 Jean-Luc Nancy napominje da je umjetnost ,transcendencija imanencije kao takve, transcendencija one imanencije koja ne izlazi iz sebe dok transcendira, koja nije eks-tatična, nego eks-istirajuća. «Transimanencija». Umjetnost izlaže upravo to. Ponavljam, ona to ne «reprezentira». Ona je eks-pozicija toga. Transimanencija, ili patentnost, svijeta događa se kao umjetnost, kao umjetnička djela. Stoga sama ta djela ostvaruju konačnu torziju para transcendencija/imanencija. (...) Drugim riječima i kao što svi znamo, kao što svi to kad-tad iskusimo, nije moguće (diskurzom o smislu) dirnuti u umjetničko djelo. To djelo nije moguće unijeti u element smisla, a prije svega u element nekog eventualnog «smisla umjetnosti» kao takvog (i nekog «smisla» riječi «umjetnost»), osim ako se prekine držanje diskurza (u skladu sa zakonom dodira) od strane tog «hermetizma» u kojemu se djelo isključivo samododiruje ili je sebi svoja vlastita transimanencija" (Nancy 2014: 67-68). 
se oblikuje figura žene umećeš semantičku vidljivost zbiljske žene? Zašto dočitavaš nečitljivo?

Prije negoli nastavimo putem koji vodi do mjesta susreta s Matoševim femininim idealom treba zastati i zapitati se kako uopće znamo o čemu je u toj nespoznatljivosti riječ. Čini se da Matoša vrijeđa to doslovno, vulgarno čitanje sadržaja ženskih figura u njegovu opusu. Očito postoji nešto što se prema njegovu sudu tome snažno opire. Usudili bismo se reći da otpor pruža sama retorika femininosti koja nije ni doslovna, ni jednosmjerna. U tekstualnom kretanju figure žene i općenito spolnosti u Matoševu radu postoji neko trajno nečitljivo kolebanje. Ta nesmiriva i nepronična oscilacija spolnih suprotnosti Matoša doslovno opsjeda. Pišući tako u „Savremeniku” o crticama Isidore Sekulić, on zapaža:

U posljednje vrijeme ima mnogo novosti kod Srba i Hrvata, ali kako ih ima malo, vrlo malo literarnih, pročitavši u ovom listu Bure pomislih: - Za tom tobožnjom Isidorom Sekulić krije se jamačno muškarac rafinirane, ženske osjećajnosti što nas mistificira ženskim pseudonimom jer danas nema žene što bi mogla napisati ovo (...) uvjerih se, e je to odista ženska knjiga, jer je mogaše napisati tek žena, poznavajući izvrsno sebe i svoj dar (...). Dok je osjećanje estetičko dano tek rijetkim muškarcima, razvijeno je kod svake žene. Dok su gotovo svi muškarci prostaci, iz svake žene možete za nekoliko mjeseci napraviti kontesu. Genij je hermafrodit i kao muški talenat što je pun žene, tako je ženski pun muških elemenata. I Ahil se odgajaše među djevojčicama (Matoš 1952: 256 i 264; istaknuli T.V. i I.Ž.).

Onkraj Matoševa maskulocentričkog seksizma, ali, usudili bismo se reći, i feminizma, probija u njegovu radu to mnogo zanimljivije područje koje književnost povezuje s kolebljivošću spolnosti. „Genij je hermafrodit”, tvrdi Matoš - on je po svemu sudeći materijalizacija neke uskomešanosti koja nema ishodište. Genij stoga nije ni izvoran, ni jedan, njegov je identitet, postoji li uopće, odgođen, mnoštven, višesmjeran - ,muški talenat što je pun žene (...) ženski pun muških elemenata" (Matoš 1952: 264). Genij je mêlée (Nancy) - u njemu se dakle neće smjestiti potpuna čistoća sebstva, ali ni potpuna čistoća njegove pomiješanosti (mélange) s kakvom drugošću. Ono što Genij donosi kao svoju suštinu, nepojmljivi je kontakt, izloženost svake jedinstvenosti mnoštvu, nedogledno dijeljenje prekoračenja, bliskost kao tuđost. Genij, na koncu, nije tek spoj istoga i drukčijega, identiteta 
i razlike, u njemu se neće razabirati što je spojeno - on je apsolutna heterogenost koja briše trag svakoj homogenosti (Nancy 2000). Očito je da ono što Matoš naziva „osjećanjem estetičkim” nema temelj. To nije znanje osigurano stabilnošću neke svijesti, nego ludilo retorike koja uključuje isključeno, udomaćuje strano, otvara mjesto onome što se ne može čitati ili misliti.

Kako misliti nemislivo, kako čitati nečitljivo? - pitanja su kojima želimo pristupiti s obzirom na ulogu spolnosti u Matoševim novelama te s time povezivom retorikom femininosti. Posve je razvidno da su prema Matošu spolnost i ženskost proturječni koncepti. Ta proturječnost u njegovim tekstovima, tvrdimo, nastanjuje svako čitanje, hvata ga, uvlači u sebe, i nužno mu izmiče. Čitljivost spolnosti i ženskosti u Matoša nije zajamčena ni uvidima Genija, ni genijalnošću interpretatora. Možemo, zapravo, kazati da je nečitljivost spolnosti i ženskosti to što omogućuje čitanje. Tu će nam biti od koristi psihoanalitičko shvaćanje spolnosti. U tekstu Divlja psihoanaliza (1957) Freud ukazuje na interpretacijska zastranjenja koja se javljaju kada se seksualnost svede na njezino popularizirano tumačenje i na čisto tjelesnu, somatsku pojavu. Slijedeći ga u tome, Shoshana Felman napominje da je seksualnost paradoksalna jer je i više i manje od spolnog čina (Felman 1982: 102-112). U seksualnosti nije važno značenje seksualnosti, nego složen odnos seksualnosti i značenja: to je odnos koji nije odmak od doslovnog značenja, nego problematiziranje same doslovnosti. Freud pak ističe da je ljudska spolnost dvostruko kodirana i ta se njezina dvostrukost očituje u nemogućnosti izjednačavanja, uravnoteženja ili mirenja normalne i perverzne seksualnosti, tjelesnog i psihičkog užitka, nagona i objekata i slično. Spolnost je, prema Freudu, najprije napetost između dviju sila: libida koji je neumjeren i potiskivanja libida. Potiskivanje je sastavni dio spolnosti i on je u kontradikciji s oslobođenim libidom. Značenje seksualnosti zapravo je kontradikcija, opstrukcija ili dokidanje značenja. Upravo to tvrdi i Lacan kada govori da seksualni odnosi ne postoje, zapravo da postoje kao vlastiti promašaj, oni uključuju vlastitu negaciju. Zadovoljstvo, pa i seksualno zadovoljstvo, sadrži potiskivanje zadovoljstva kao svoju esenciju, a ne kao neku slučajnu nezgodu (Lacan 1968).

Čitamo li spolnost na taj način, a retoriku razumijevamo poput de Mana, kao upotrebu jezika koji stalno referira na nešto drugo (de Man 1983), onda - s obzirom na način retoričke izvedbe spolnosti i ženskosti u Matoševoj 
novelistici - svako njihovo čitanje nužno promašuje. Retorika femininosti i spolnosti nastaju kao snažan izazov doslovnosti književnog značenja i suštinski su nečitljivi. Matoš je toga, vidjeli smo, bio itekako svjestan. Štoviše, njegov koncept artizma kao da se stalno okreće oko tog sljepila. Zato ga tako gorljivo brani - on razumije da tek sljepilo uvidu (de Man) omogućuje pojavljivanje. Pitanje je, dakle, što vidimo u toj tamnoj mrlji teksta ako ne vidimo književno značenje? Kako čitamo nečitljivo? Teza od koje polazimo jest da odnos prema nerazmrsivim čvorovima tekstualnih kontradikcija u Matoševoj novelistici - čvorovima poput spolnosti i retorike femininosti - ukazuje na učinke njihova interpretativnog osvjetljavanja, posve precizno na učinke čitanja. Na tim je mjestima iščašena i zapretena jezična materijalnost značenjski nepronična, ali je vidljiv njezin tekstualni rad - on je pokazatelj načina analitičkog otpetljavanja i osmišljavanja onoga što se ne može otpetljati i što se ne može osmisliti. Ta neka čudnost teksta mami čitanja, formira ih, strukturira i oblikuje bez njihova znanja.

Dosadašnja čitanja Matoševa književnog modernizma baš su ta neprozirna mjesta pokušavala privesti određenim vidovima racionalnosti, objasniti ih, normalizirati ili su ih pak zanemarivala. Matoš je sâm često proglašavan pjesnikom učenim i racionalnim; retorika femininosti čitana je u svjetlu tipskih ženskih identiteta i kao manje-više jasna poetička ili politička funkcija figure žene; a zazornost se spolnosti pak gotovo redovito harmonizirala uparivanjem s konceptom tanatosa, fenomenologizirala se pod izlikom kakva biografskog podatka ili se naprosto omalovažavala kao ornamentalni dodatak dubljim poetičkim istinama ${ }^{3}$. Odmah napominjemo

3 Primjerice, Dubravka Oraić Tolić u Matoša je prepoznala „dvije slike žene: žena-majka-domovina i žena-ljubavnica-ljepotica (apstraktni ideal ljepote, «vječno žensko», Žena kao takva). Žena-majka-domovina utemeljila je nacionalnu notu Matoševe patrijarhalne filoginije, a žena-ljubavnica-ljepotica njegov esteticizam, i u iskazima o ženama u feljtonistici i kritici i u imaginacijama žena u poeziji i umjetničkoj prozi” (Oraić Tolić 2013: 181-182). Ambivalentnu i nedosljednu reprezentaciju žena ona objašnjava Matoševim svjetonazorom „patrijarhalnog filogina” (ženoljupca zaljubljenog u imaginarnu sliku žene). Prema njoj za Matoša postoji „,bit” žene, ali i nepremostiva razlika između muškarca i žene. Oraić Tolić Matoša vidi i kao ambivalentnog antifeminista, koji s jedne strane odbacuje smjerove feminističkog pokreta u svijetu, ali s druge strane prihvaća one oblike emancipacije žena koji se uklapaju u njegovu projekciju žene i njegovu ideju nacije. S tim da kao prijelomnu točku vidi 1908. godinu kad se Matoš vraća u Hrvatsku. Europski Matoš naspram hrvatskoga je, prema Oraić Tolić, konzervativniji i skloniji tradiciji. Tako odnos ranog Matoša prema 
da ovdje nije riječ o tome jesu li ta čitanja pogrešna ili ispravna, nego je u igri pitanje što su ona, kako nastaju, na koji se način strukturiraju, što ih pokreće i u kakvom odnosu njihova znanstvena istina stoji spram onoga što se prema našem mišljenju ne može znati.

U noveli Cvijet sa raskršća pojavljuje se ženski lik - Izabela. On se u našoj znanosti o književnosti i u školskom sustavu obično razumijeva kao simbol čiste ljubavi i nedostižnog ideala. U svojoj pomnoj stilističkoj analizi Frangeš tvrdi da „cvijet nije cvijet, nego slijepa djevojka (čak: djevojčica)" (Frangeš 1986: 189). Ona je simbol netaknutog savršenstva. Dajući, poput pripovjedača, riječ glavnom junaku Solusu, Frangeš to ovako sažima: „To je, dakle, ljubav koju tražim bez prestanka, za kojom čeznem toliko godina kroz tolika lutanja i tolika potucanja. (...) To je čas veličanstven, kad ljubav zaustavlja sve, i vrijeme i zbivanje i kad se sve pretvara u silovit osjećaj” (Frangeš 1986: 204). Unatoč Frangešovu zaključku da se poetska i simbolička poruka Matoševe novele dade jasno iščitati kao svojevrstan biblijski izgon junaka iz raja u pakao lutalačke sudbine, u njegovoj analizi ostaje posve nejasno tko koga i tko što simbolizira. Naime, Frangeš je i te kako svjestan povezanosti Izabelina lika s drugim dvjema ženskim figurama koje se u noveli pojavljuju - Gorgonin kip i gospođa Avantira - ali je njegova interpretacija te povezanosti posve proturječna. Evo završnog dijela analize:

Ručavši skromno, putnik se iz Gorgonine fontane napio vode, i tako „opijen” usnuo; probudio se, ugledao Izabelu, osjetio ljubav i bio izgnan iz „raja”; a onda se - na kraju - razbuđen i ojađen, ponovno napio istog „okamenjujućeg” napitka i otputio za lutanjem, za svojim udesom. To je ujedno poetska i simbolička poruka Matoševa Cvijeta sa raskršća (Frangeš 1986: 206).

feminizmu čita kao ambivalentan, a kasnoga kao antifeminističan, osvrćući se doduše uglavnom na feljtonističku prozu. Lik Alfreda Kamenskog iz novele Camao promatra pak kao esteticističkoga androginog muškarca. U okviru feljtonističkog diskursa autorica govori i o svojevrsnoj rodnoj zamjeni uloga, ali su one u funkciji stilskog ludizma i karnevalizacije. Naposljetku Oraić Tolić razdvaja i slike stvarnih žena tvrdeći da je liberalniji rani Matoš projicirao femme fatale poput Isadore Duncan, a kasniji i konzervativniji femme fragile poput Ljerke Šram. Suzana Coha u tekstu Tko (ni)je ,spoznal” (n)i ,prepoznal' Kipa domovine? Od Štoosa preko Matoša prema Krleži (Coha 2012: 39-44) analizira Matošev prikaz žene, kako u pjesmama, tako i u prozi, i kao karakterističnu prepoznaje sliku koju Oraić Tolić naziva „ženom-majkom-domovinom”. 
Frangeš ne odgovara na pitanja koja bi se tu mogla pojaviti: kako se okamenjivanje može dovesti u vezu s lutanjem, zašto Izabelino savršenstvo ne zaustavlja onoga koji za savršenstvom traga, kakav je to raj kojemu je Gorgona čuvarica i kakvo je to izgnanstvo ako Solus doslovno žudi za njim. Malo prije toga definitivnog zaključka svoje analize Frangeš napominje da je Avantira gospođa lutalice Solusa, da je lijepa i slijepa poput djevojke Izabele i zamamna kao mramorna zmijokosa Gorgona. Premda se iz Matoševa teksta takve informacije ne daju iščitati, Frangeš, kao uostalom svi prije i poslije njega, gospođu Avantiru ne povezuje s likom žene, nego sa simbolom lutanja kojem je Solus čvrsto odan. Međutim, iz usta glavnog junaka mi doznajemo samo ono što je i Frangeš prepoznao - riječ je o lijepoj i slijepoj, slobodnoj, maglovitoj vili, gospođi koja ga vodi po njegovu putu. Postoji, dakle, očit paralelizam u prikazu Avantire i Izabele iz očišta Solusa, ali ono što je presudno jest to da i jedan i drugi prikaz obilježavaju nesigurnost i figurativnost ${ }^{4}$ te da ni jedan ni drugi ne definira ontološki ili ontički status pojave. Drugim riječima, iako se čini da je Izabela prikazana kao reprezentant zbiljske osobe, a da je Avantira samo drugo ime za lutanje, to se iz samog teksta ne može razabrati. Treća ženska figura, Gorgona, nedvojbeno je prikazana kao kip i ona označava Solusov susret s Izabelom te njihov rastanak i Solusov odlazak ususret Avantiri.

Bez ikakve sumnje, retorika femininosti u samom tekstu nije ni doslovna ni jednosmjerna. Zapravo, moglo bi se kazati da je ona duboko proturječna i da figura žene ne može biti čitana kao simbol koji povezuje dvije jasno odijeljene suprotnosti u neku harmoničnu cjelinu. Figura žene u Cvijetu sa raskršća, tvrdimo, nije čak ni figura koja bi u tradicionalnom smislu prenosila značenje - riječ je o označitelju koji paradoksalno referira tek na odgodu vlastita značenja. Ustvrdimo li da je Izabela simbol čistoće i savršenstva, moramo prihvatiti činjenicu da Solusov prikaz čistoće pati od jezičnog onečišćenja, a prikaz savršenstva od izobličenja. Dovoljno je pogledati listu kulturnih

${ }^{4}$ O načinu prikaza Izabele iz očišta Solusa Tvrtko Vuković pisao je: „Retorički repertoar kojim se Solus, modernistički subjekt, služi u iscrtavanju Izabelina «lelujavog» obličja združuje niz proturječja: snovično i fantastično te vilinsko i bajkovito s realističnim, nokturalno s blještavim, nebesko i nevino s putenim. Osjećaji koji ga pritom obuzimaju također su dvojbeni. On ih prikazuje kao «mučnu i sretnu neizvjesnost». Uglavnom, ni Izabelinu nepreglednu divotu ni svoja zbrkana čuvstva Solus ne uspijeva jednoznačno logički posredovati. To potvrđuju česti nedovršeni, otvoreni ili «zbrkani» iskazi te lančano, načelno nezavršivo, nizanje usporedbi" (Vuković 2006: 170). 
citata i označitelja - od van Dycka do Beethovena - koje Solus upošljava prilikom predočavanja suštine Izabeline ljepote da se shvati kako reprezentacija žene-ideala unutar same priče počiva na antiesencijalističkoj logici suplementarnosti i uokviravanja (Derrida 1990, 1992). Solus Izabelu predočava kao „čedo iz okvira” - a iz bitka ljepote taj regulirajući i samoumnožavajući okvir ne može biti izuzet. Pokuša li se u ovoj priči razabrati neka poetička funkcija žene, onda se može reći da ona počiva u trajnoj odgodi stabilne poetike i uopće svakoga drugog smisla. Igra označitelja za žene i oscilacija ženskih uloga iznosi na vidjelo rad onoga što u noveli nema značenje i uvijek ostaje nečitljivo. Upravo zato Solus i može kazati Izabeli da ne žali za vidom. „Čovjek vidi da ne vidi, i žali što je vidio. Kada hoću da gledam, zatvaram oči kao vi i gledam u tminu, u sebe" (Matoš 1973a: 262). To gledanje u vlastitu tminu, u ništavilo, narativna je formula ove Matoševe novele.

Kada Solus Izabelu gleda i opisuje, nužno je izobličuje. Svaki je uvid ovdje osovljen o sljepilo - preko te nečitljivosti klizi retorika femininosti, ali i svaka njezina moguća interpretacija. Gorgona, Izabela, Avantira - kakva je onda veza toga svetog trojstva ženstva i Solusove sudbine? Odgovor se može napipati ako se Cvijet sa raskršća pročita kao naracija koja pokušava razumjeti epohu na prijelazu iz XIX. u XX. stoljeće. U tom smislu topos, zapravo anti-topos, raskršća upućuje na paradoksalnu prostornost, zazornu zonu koja istodobno pripada svim ukriženim putovima i ni jednom u cijelosti. Solus je očito čovjek raskršća - on je kao subjekt radnog procesa i tržišta nevidljiv, a u prostornom smislu posve izmješten. Kao takav predstavlja prijetnju mehanizmima discipliniranja tijela, strategijama odvajanja, kontrole i identifikacije razvijenima u ekonomiji i kulturi devetnaestostoljetnog društva. Zona raskršća, njegova nestabilna i prolazna geografija, ovdje je proturječno spojena s mitskim likom Gorgone. Užas pred kojim ljudsko biće ostaje skamenjeno i ideja raspršenosti subjekta uranjaju jedna u drugu. Slijedom te komplicirane prepletenosti kreposna i nevina djevojka Izabela u strukturnom rasporedu pripovjedne građe funkcionira upravo poput Gorgone ${ }^{5}$. Za

${ }^{5}$ Ovdje nije na odmet dodati da Gorgone simboliziraju susret s vlastitom izopačenošću u području spolnosti, društvenosti i duhovnosti. Solus očito na tom raskršću susreće vlastitu psihičku distorziju. Prema Freudu Gorgona je utjelovljenje primordijalnog straha od kastracije. Međutim, u Matoševoj noveli Solus taj užas prevladava, zapravo, na paradoksalan način, uranjanjem u užas flanerističke nestrukturiranosti. Radikalna izopćenost modernističkog umjetnika ekvivalentna je psihotičkom poremećaju pomanjkanja autoriteta. 
flaneristički subjekt, koji bodlerovski nastanjuje pukotinu društvenih i kulturnih konvencija, Izabelina savršena ljepota, ljubav, ćudorednost te, na kon$\mathrm{cu}$, socijalna konvencionalnost predstavljaju prijetnju radikalnog zauzdavanja pravilima, riječju okamenjivanja. No Izabela je na određeni način srodna i Avantiri, muzi landranja. Poput nje za prikaz je posve neuhvatljiva. Neživo i živo, užas i ljepota, dobrota i zlo, prikazivo i neprikazivo - pomiješani su tako da se više nikakva sigurna granica među njima ne može povući. Svaki pokušaj čitanja te višesmjenosti, pridavanje značenja višeznačnim označiteljskim proklizavanjima, prisvaja silu kojoj se sâm tekst stalno otrgava.

Ovome se može dodati još jedan uvid. Izabelin je lik u određenom smislu nositelj patrijarhalnih vrijednosti. Ona je biće privatnosti i kao većina žena na prijelazu iz XIX. u XX. stoljeće ostvaruje se u prostoru doma i u okviru obiteljskih rituala i pravila. Muškarac je, pak, onog vremena pretežno biće javnosti, ekonomije, tržišta i društvenosti. Solus, u tom smislu, ne pripada ni jednoj od tih zona. On doslovno stoji na raskršću javnoga i privatnoga, moralnoga i opscenoga, realizma (fotograf) i artizma. Čini se da Solus od Izabele mora odustati ponajviše zbog strukturnog položaja koji zauzima. Izmještenost umjetnika u prostoru onodobne kulture opće je mjesto. No u Solusu susrećemo i nešto drugo - radikalnu nečitljivu drugost kao neubrani „cvijet sa raskršća”. Naime, odustajući od Izabele, on pristaje na Avantiru - njegov je postupak utjelovljenje čiste nemogućnosti. Shvatimo li lik gospođe Avantire kao označitelj nepristajanja, Solus je - taj koji pristaje na nepristajanje - ime za aporiju. Njegova ljepota krajnja je iščašenost - teza i protuteza bez sinteze, klizište onodobnih ekonomskih, političkih, etičkih i poetičkih sustava, ono što izmiče racionalnom, metodološki ustrojenom i normalnom razumijevanju teksta.

Pristupa li Solus idealu žene tako da ga pristupanjem uvijek-već napušta, ako je ideal odgođen tako što je doslovno naplavljen tragovima njegova čitanja, utjelovljuje li on sam proturječje sljepila uvida te, na koncu, radi li novela, seksualiziranom retorikom femininosti ponajprije, kao kakav tekstualni mehanizam koji se opire izravnom razumijevanju ženskosti, onda su njezina školska i akademska čitanja, zapravo, nemoguć pokušaj da se nečitljivo pročita. Te analize znanstveno znanje - bilo o Matoševu razumijevanju femininosti bilo o shvaćanju čitanja modernističkog teksta - duguju onome što sama priča organizira kao svoj izmičući temelj, nespoznatljivu jezgru. Shvatimo li, među ostalim, Cvijet sa raskršća kao priču o razumijevanju 
ideala, onda njezin rad pokazuje da to razumijevanje mora ideal iznevjeriti, napustiti, učiniti ga ne-idealnim. Uvid u čistoću, kao što Solus napominje, zapravo je poniranje u tminu. Sljepilo je, drugim riječima, jedini način gledanja. Možda ova Matoševa novela svoju žilavost i kulturni utjecaj duguje upravo tome što u sebi otvara pukotinu u koju njezine glavne estetičke teze stalno propadaju. Dosadašnje su analize femininosti u Matoševoj novelistici, unatoč nesmirivoj nestabilnosti koncepta, težile stabilizirati ga i tako su, prividom konačnoga znanstvenog znanja, začepile ono mjesto na kojemu čitanje buja. Poput Izabelina oca koji proturječan odnos fatalnih ljubavnika čita doslovno i Izabelu odvlači u normalnost ženske uloge, tako i dosadašnja čitanja ove novele ambivalentnu i nejasnu retoriku femininosti i spolnosti odvlače u zonu jasnoće i poetičkih pravila. Vjerujemo da su pritom ostala slijepa za samo sljepilo kao nužan uvjet čak i književnoznanstvenog uvida. Čini se da je hermafroditstvo Genija Matoševe poetike bilo lakše prešutjeti kako bi se snažnije čuo glas zdravog razuma koji Hermesa želi vidjeti na jednoj, a Afroditu na drugoj strani - bilo razreda bilo društvene zajednice.

\section{Literatura}

Coha S., 2012, Tko (ni)je „spoznal” (n)i ,prepoznal” Kipa domovine? Od Štoosa preko Matoša prema Krleži, „Kaj - časopis za knijževnost, umjetnost, kulturu” br. 6, str. 25-52.

Derrida J., 1990, Istina u slikarstvu, prev. S. Ćuzlan, Sarajevo.

Derrida J., 1992, „That Dangerous Supplement...”, u: Acts of Literature. Jacques Derri$d a$, ur. D. Attridge, New York-London, str. 76-109.

Felman S., 1982, Turning the Screw of Interpretation, u: Literature and Psychoanalysis. The Question of Reading. Otherwise, ur. S. Felman, Baltimore-London, str. 94-207. Felman S., 2003, Writing and Madness, Palo Alto.

Frangeš I., 1986, Cvijet sa raskršća, u: idem, Nove stilističke studije, Zagreb, str. 189-206.

Freud S., 1957, Wild Psycho-analysis, u: idem, The Standard Edition of the Complete Psychological Works of Sigmund Freud, vol. 11, prev. J. Strachey, London, str. 219-230.

Lacan J., 1968, Discours de cloture des journées sur les psychoseschez l'enfant, <http:// aejcpp.free.fr/lacan/1967-10-22.htm>, 16.02.2014. 
de Man P., 1983, Blindess and Insight: Essays in the Rhetoric of Contemporary Criticism, Minneapolis.

de Man P., 1986, The resistance to Theory, Minneapolis.

Matoš A.G., 1952, Kritike A.G. Matoša, u: Hrvatska književna kritika IV, ur. M. Matković, Zagreb.

Matoš A.G., 1973a, Sabrana djela, sv. 1, Iverje. Novo Iverje. Umorne Priče, ur. D. Tadijanović, Zagreb.

Matoš A.G., 1973b, Sabrana djela, sv. 19, Pisma I, ur. D. Kapetanić, Zagreb.

Nancy J.-L., 2000, Euology for the Mêlée, u: eadem, Being Singular Plural, Stanford, str. $145-158$.

Nancy J.-L., 2014, Muze, prev. V. Mikšić, Zagreb.

Oraić Tolić D., 2013, Čitanja Matoša, Zagreb.

Vuković T., 2006, Izabelin cvijet i Cvjetina peta. Sublimno i zazorno u Matoševim novelama Cvijet sa raskršća $i$ Balkon, u: Znanstveno djelo prof. dr. sc. Milivoja Solara. Hrvatska književnost 20. stoljeća, različite ideje i funkcije književnosti, ur. B. Bošnjak, Zagreb, str. 167-174. 